From the ancient Silk Road to the belt and road initiative: Narratives, signalling and trust-building

Zhao Y.,Tan-Mullins M.

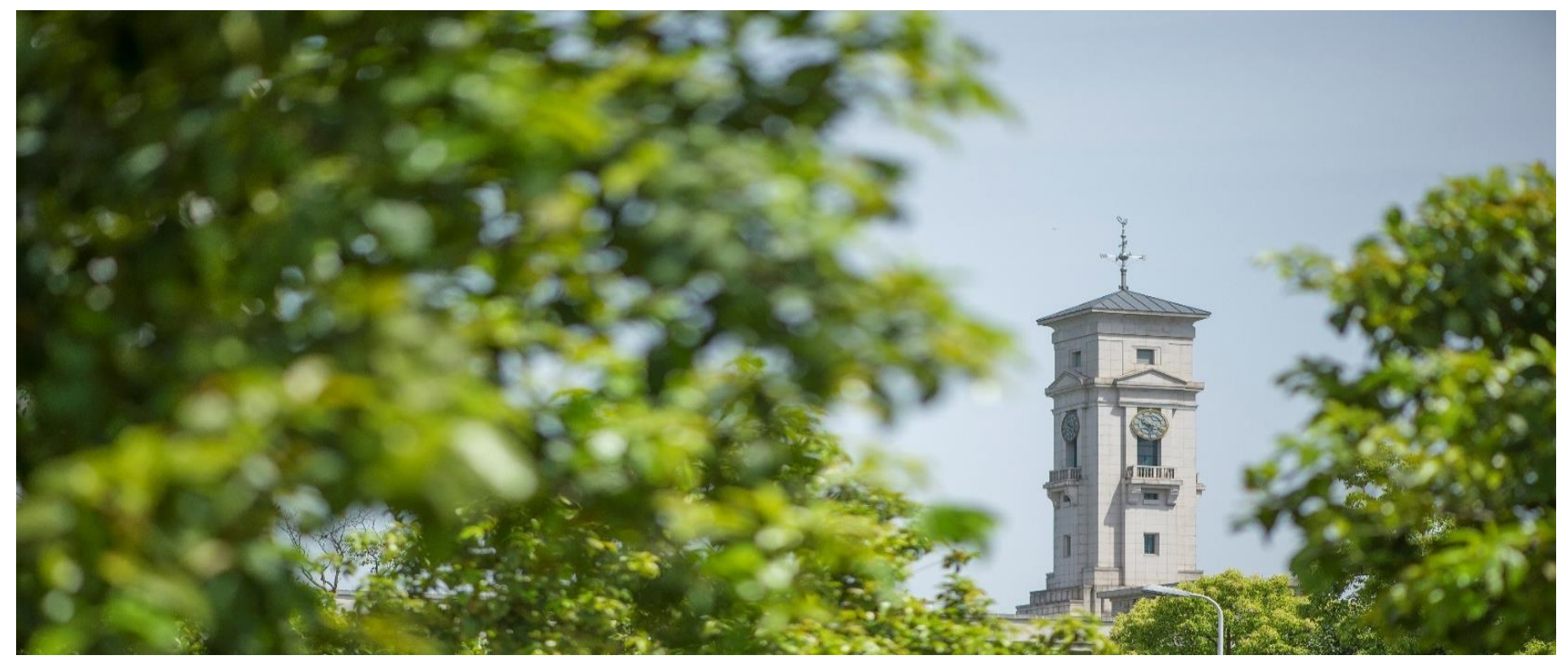


University of Nottingham Ningbo China, 199 Taikang East Road, Ningbo, 315100, China

First published 2021

This work is made available under the terms of the Creative Commons Attribution 4.0 International License:

http://creativecommons.org/licenses/by/4.0

The work is licenced to the University of Nottingham Ningbo China under the Global University Publication Licence:

https://www.nottingham.edu.cn/en/library/documents/researchsupport/global-university-publications-licence.pdf Nottingham 


\title{
From the Ancient Silk Road to the Belt and Road \\ Initiative: Narratives, signalling, and trust-building
}

\begin{abstract}
Narratives help in interpreting and understanding surrounding political realities. Yet, the divergence of narratives may also create distrust, and it is an important reason for greatly diverging perceptions of the Belt and Road Initiative (BRI) between China and the international community. This paper explores how trust can be bridged between different narratives. It discusses the notions of trust and how the Chinese concept of 'brightness' contributes to a strategic signalling process for trust-building in strategic cooperation. This paper proposes that trust-building is a process of signalling and knowledge building. Only when the signal sent for strategic cooperation fits the other parties' knowledge about the sender, can the trust-building process succeed. This compatibility between signals and developed knowledge can be the result of several rounds of signalling, in which the signal sender's honesty regarding their self-interests and intentions is the necessary pre-condition.
\end{abstract}

Key words: Trust-building; costly signals; brightness; BRI; Ancient Silk Road

\section{INTRODUCTION}

Narratives help people make sense of the world (Somers, 1994: 606), and in interpreting and understanding the surrounding political realities (Patterson and Monroe, 1998:321). These give people reasons to act (Franzosi, 1998), but at the same time act as ruling tools. From a postcolonial perspective, Datta-Ray (2015) demonstrates how dominant Western diplomatic narratives suppress and marginalise India in important areas of international affairs, and he thus claims the need for India-oriented (non-western) narratives in diplomacy. Although China's contemporary foreign policies are not usually interpreted in terms of post-colonial narratives, China faces a similar situation to India in suppression and marginalisation in diplomacy, and thus there is a similar demand for Chinese-oriented narratives. 
The problems China faces can be illustrated by attitudes surrounding the Belt and Road Initiative (BRI). From the Chinese perspective, the BRI will enable China to engage with other fast emerging Asian markets through bilateral infrastructure and trade and investment cooperation, and allow these Asian countries to tap into China's huge domestic market (Irshad et al., 2016) While China regards the BRI as a global public good, believing it will bring huge development to countries within the BRI scope, criticisms of the intentions and possible impacts of BRI projects have emerged in host countries and the rest of the world. A report in the Financial Times suggested that there are at least 234 BRI projects suffering setbacks, such as lack of social acceptance (Kygne, 2018).

While many scholars attribute the low social acceptance of the BRI to technical issues (Russel and Berger, 2019; Yean, 2018; Liu and Lim, 2018; Baltensperger and Dadush, 2019), other scholars point to the divergence in perceptions of the BRI as the result of different political and economic narratives (Blanchard, 2018; Callahan, 2016; Sidaway and Woon, 2017). Failures, or slow progress, in project management of international investments are not rare in the era of globalisation, and do not inevitably have political consequences. A lack of understanding of the BRI signals from a different narrative background creates mistrust and misunderstanding (Yahuda 2013; Kynge, 2018; Juan, 2018). Yet as this article will argue, some strategic signals sent via the BRI have received greater acceptance than others sent via the same channel.

This paper aims to address the question of how trust may be bridged across differing narratives in International Relations (IR) by linking the notion of strategic signalling with the Chinese concept of 'brightness'. Specifically, what factors condition the success of strategic signals for trust-building? It argues that trust in strategic cooperation is the result of a series of signals and knowledge building where the signal sender's honesty regarding selfinterests and intentions, acts as the conditional factor.

Following this first introduction, the paper will be divided into three further sections. Section two discusses the notions of trust and how the strategic signalling process contributes to trust-building. The third section tests this framework with two case studies. One is the construction of the ancient Silk Road in around 139-114 B.C.E., when Zhang Qian of the Han dynasty connected China and Central Asia for the first time. The other is the modern BRI Launched in the 2010s. Both cases are regarded as initiatives by China in changing the regional order, and both encountered, or are encountering, problems originating from different narrative backgrounds. Section four concludes by explaining how the theories of strategic signalling and the notion of brightness could help build trust between China and the rest of 
the world regarding the BRI project.

\section{SignALLING AND TRUST-BUILDING}

Trust is an important concept in the field of International Relations, especially in the processes of conflict resolution and peace-building between countries. Rousseau et al. (1998:395) define trust between two parties as 'a psychological state comprising the intention to accept vulnerability based upon positive expectations of the intentions or behaviour of another'. Others regard it as a part of rational decision-making preferences in relation to the external environment (Hollis, 1998:14). Hoffman (2002:366) argues that trust is a willingness to take risks on the behaviour of others, based on the belief that potential trustees will 'do what is right'.

Trust-building across narratives is difficult due to the divergence in perception between the senders and the receivers, and to the complexity of decision-making with regard to the interpersonal nature of trust-based relationships (Booth and Wheeler, 2008; Wheeler, 2012; Rathbun, 2011, 2012). It is an incomplete information game (Kydd, 2000), and thus cannot be explained in the context of available information and specific reciprocity alone (Rathbun, 2011, 2012). However, trust-building is not impossible between states. Jervis (1976) argues that although misperception occurs far more frequently than is normally realised, the actors can try to minimise it by trying to see the world the way the other sees it, or by examining the world from varied perspectives.

How is trust built? Signalling theory views trust development as a signalling process. Kydd (2000:333) states that 'trust can be established and fostered by small, unilateral cooperative gestures that initiate chains of mutually rewarding behaviour'. These gestures are signals. This theory helps to describe the mode of behaviour of two nations in interaction (Breslin, 2018).

However, not all signalling processes can generate trust. Received signals might lead to erroneous inferences. Senders may be able to deceive receivers by skilful use of signals; furthermore, contextual and/or reputational beliefs may differ in the extent to which they reflect the true intentions and abilities of senders (Jervis, 1976). Decision-makers tend to evaluate to what extent a signal reflects the true intention of the signal sender (Glaser, 2010).

Scholars, therefore, place a strong emphasis on the significance of costly signals in broadcasting sincerity in cooperation (Glaser, 2010; Larson, 1997; $\mathrm{Pu}, 2017)$. Costly signals are gestures that involve a high cost to the sender in a reassurance game. In contrast to cheap signals that can be easily 
retracted, players would not send (or at least would hesitate to send) costly signals if they were not sincere about their cooperation (Kydd, 2000). Costly signals, therefore, modify the expectation of the counterparties enabling cooperation (Kydd, 2005:187). For instance, the restrictive membership accession procedures of international institutions follow the logic of costly signalling by serving as filters that enable the candidate to prove their sincerity in seeking membership (Kydd, 2001:821).

Fearon (1997) distinguishes two types of costly signals that states might use for communication purposes. Firstly, when players try to communicate willingness of cooperation, they can send signals that 'tie their hands' and limit room for manoeuvre. It increases 'the costs of backing down if the would-be challenger actually challenges but otherwise entails no cost if no challenge materialises' (Fearon, 1997:70). For example, when state leaders make a public statement, they send a 'hand-tying' signal by creating potential audience costs among their domestic political constituency. If their actions do not match their words, they risk domestic political opposition (Fearon, 1997). The other type of costly signal is one with a sunk cost. Sunk-cost signals are 'actions costly for the state to take in the first place but do not affect the relative value of fighting versus acquiescing in a challenge' (Fearon, 1997).

However, there is still no guarantee that signals with high 'hand-tying' costs and sunk costs will always generate trust. The BRI appears to be a series of costly signals that involves both high 'hand-tying' costs considering its important position in China's foreign policy, and high sunk cost through the numerous infrastructure investments overseas. Yet, BRI projects still suffer from low social acceptance in neighbouring countries. This example illustrates how current strategic signalling theories fail to explain the puzzle of trust-building.

\section{The Virtue of 'brightness'}

The Chinese Pre-Qin masters understood that trust-building between states is difficult. The key to trust-building is to avoid the risk of being deceived. Han Feizi states that for medium-size states, security cooperation with small states may not ensure their own survival, but cooperation with large states risks the chance of being deceived and thereby being controlled (Zhang, 2006). In order to reduce risk in cooperation and to demonstrate their sincerity, states in the Spring and Autumn period exchanged princes (sometimes the crowned princes) as hostages. This kind of action can be regarded as sending costly signals for trust-building. Pre-Qin masters, however, also understood that costly signalling does not always guarantee 
the success of trust-building.

Zuo Qiuming, the pre-Qin historian author of Zuo Zhuan (左传) has documented a case in which the King of Zhou and the Lord of Zheng exchange their sons as hostages to enhance their bilateral relationship; however, the Lord of Zheng still secretly sent troops to seize Zhou's grain. Zuo Qiuming thus points out that 'even with princes as hostages, there might not be sincere trust between states. If states dealt with others with brightness, and regulated their own behaviour according to ritual norms, the trust would be solid even without hostages'(Guo, 2016: 21).

For the ancient Chinese, brightness (明) is an important quality of noble and virtuous men. Zhu Xi (朱喜also known as Zhuzi), one of the most important Confucian scholars of the Song Dynasty, values 'understanding the meaning of brightness' as the first and the most important step of learning (Hu and Zhang, 2017).

Brightness originally means the light, and everything that the light touches, and as a moral quality it requires rulers and virtuous men to be honest as to their intentions and to act in accordance with clear and transparent rules. Mencius indicates that if rulers can act in bright ways, even large states will be wary of challenging them (Liang 2015). Xunzi claims that with the virtue of brightness, kings can rule their countries well, establish good relations with other countries, and rule 'All Under Heaven (Tianxia)' (Zhang, 2012).

The notion of brightness opposes the use of subterfuge and conspiracy in domestic politics and interstate relations. Xunzi states that if a state deceives its people for benefits, then the people will not be honest with the ruler; if the state deceives friendly states for self-benefit, it would not be able to deter rival states, or be trusted by the friendly states (Zhang, 2012). He further indicates that one can filch a state through tricks and conspiracies, but no one will be able to win 'All Under Heaven' by these means (Zhang, 2012).

For ancient Chinese masters, acting in bright ways is believed to be the key to trust-building in strategic cooperation because it could reduce potential partners' fears of being deceived. Using the language of modern IR theorists, honesty regarding self-interest and intentions could enhance the other party's confidence in cooperation because it decreases the uncertainty in the incomplete information game as trust-building.

This brightness, however, might not be automatically perceived by others. For strategic cooperative purposes, one state's honesty regarding its selfinterest and intentions needs to be transformed into the other parties' good 
understanding of this state's cooperative interests, and this transformation process can be easily disrupted, which is where the ancient Chinese masters are found lacking.

\section{Signalling With 'BRIghtNess'}

To summarise the review of the literature above, the consensus among modern IR scholars and ancient Chinese masters is that the key to trustbuilding is to decrease uncertainty in this incomplete information game. However, their emphases in trust-building process diverge. For strategic cooperative purposes, the judgment regarding whether a state will be trustworthy in a potential cooperation depends on two major factors. One is whether the signal sender might exploit others by backing down from cooperation once the proposal is accepted, which is a problem that costly signals can help resolve. The other factor is concern whether the signalled proposal reflects the true intention of the signal sender. The counterparties need to know that the signal sender does not have a hidden agenda. The ancient Chinese masters were conscious of these issues.

This paper attempts to address these two issues in order to formulate a comprehensive understanding of the trust-building process. The proposed model makes two major assumptions. First, the existence of mutual interest determines whether there is a need for strategic cooperation. That is, both parties have the internal desire to achieve strategic cooperation. Second, the decision-makers are fully rational. They tend to trust their counterparties when they believe the risk of being deceived or exploited is low. Furthermore, they should also be able to independently reformulate and update their knowledge based on newly gathered information.

This paper proposes that trust-building is a process of signalling and knowledge building. Only when the signal sent for strategic cooperation fits the receiver's knowledge about the sender, thus generating a good understanding of the sender's cooperative interests, can the trust-building process end in success. A good understanding of the sender's cooperative interests means the receiver feels confident that the signal sender is willing and fully capable in fulfilling the cooperative responsibility. This good understanding can be the result of several rounds of signalling, in which the signal sender's honesty regarding self-interest and intention is the necessary condition. 
Previous rounds of signalling

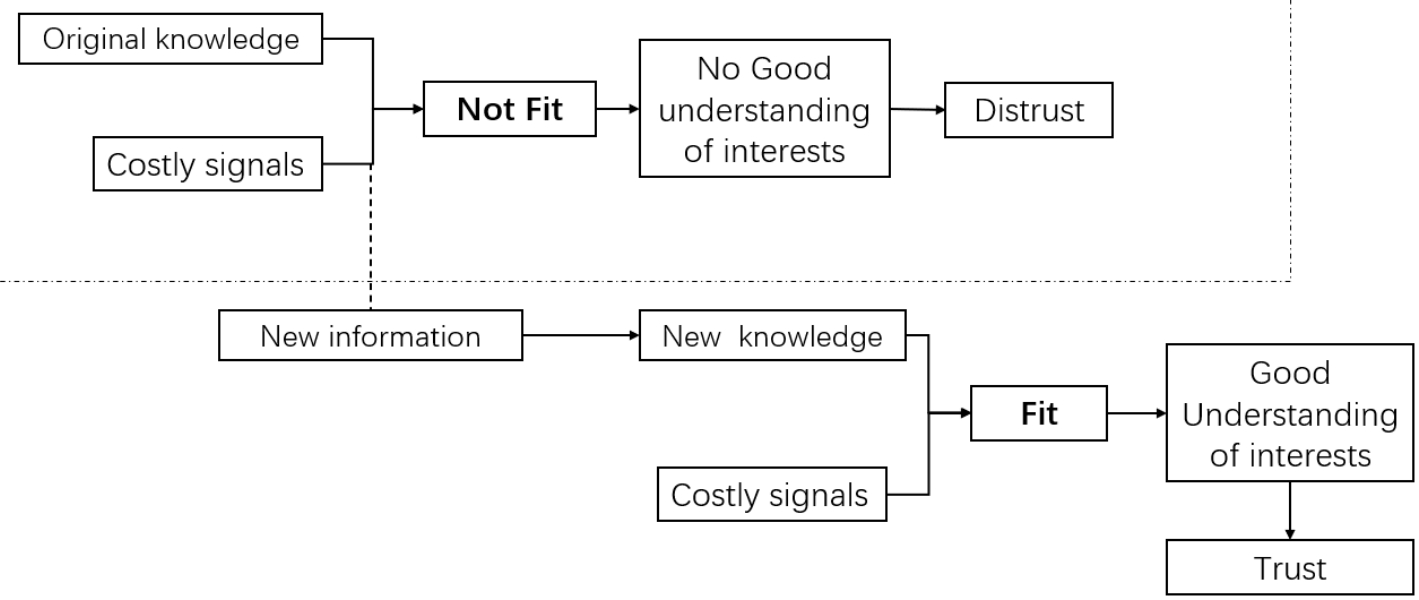

Figure 1, Trust-building as a process of signalling and knowledge building

As Figure 1 illustrates, Country B would not develop a good understanding of Country A's cooperative interests and thus feel confident about the cooperation if A's signal does not fit B's original knowledge about $A$. This original knowledge could be the product of previous experiences, images, or stereotypes. Country B, therefore, will not trust Country A and thus decline the proposal. Yet, it may not be the end of the game. Taking the costly signals in this first round as one of the sources of new information, Country B may gather further information about Country A through various means such as, investigation, negotiation, or personal interactions between state leaders (Hall and Yarhi-Milo, 2012). New information would generate new knowledge about Country A. If Country A's costly signals fit this newly developed knowledge, Country $B$ would be able to develop a good understanding of Country A's interest in cooperation and trust can thus be built.

The signal sender's honesty regarding their self-interest and intentions is the necessary condition for potential counterparties to generate a good understanding of the sender's cooperative interests. Communication and cognitive theorists point out that people with high cognitive capability can avoid being misguided and make rational choices if they have access to multiple sources of information (Zucker, 1977; Zaller, 1992; De Vreese and Boogaarden, 2005, 2006). This argument suggests that it is difficult to manipulate others' knowledge about a country, especially in a long-term trust-building process, because manipulated information will eventually be corrected by other information sources.

This signalling and knowledge building process may end in three scenarios. 
In the first scenario the signals in the following rounds fit the newly developed knowledge, and Country B's understanding of Country A's cooperative interests is improved. Trust might thus be built, and strategic cooperation achieved. In the second scenario Country B declines Country A's proposal, and Country A stops sending signals in seeking for strategic cooperation because it has manipulated information in the previous rounds of signalling to hide its true cooperative interests and intentions. The more rounds of signalling it continues to conduct, the more manipulated information will be corrected in the knowledge building process, which will further erode any trust country $B$ has in Country A. It will make cooperation unlikely. (3) Country $A$ has been honest about its self-interests and intentions, but Country B's knowledge building about Country $A$ is still incomplete. Country A may choose to continue with further rounds of signalling, depending on the potential payoffs of cooperation and the costs of signalling. If the anticipated payoff is larger than the cost of signalling, the signalling process will likely continue; if not, Country A will choose to stop sending signals. Kydd (2000:340) puts this succinctly: 'signals must be costly, but not too costly'.

\section{Two 'Silk RoAd' CASes of Trust-building}

The Silk Road has never been a specific name for one road or route. It is a general notion referring to all routes that connected China, Central Asia, the Middle East, the Mediterranean region and Europe through which people exchanged commercial goods, ideas, technology, and culture. Although it has existed for more than two thousand years, its name 'Silk Road' was first used in 1877 by the German explorer Baron Ferdinan Von Richthofen (Wood, 2002). This section examines two empirical cases where China has attempted to build trust across narratives for a change in regional order. Both cases are related to the idea of the 'Silk Road'. The first case helps to illustrate how the dynamic signalling process and knowledge building led to the establishment of trust between states with different narrative backgrounds. The second case helps demonstrate the conditions of trustbuilding in the signalling process.

\section{Case One: Ancient Silk Road in 139-114 B.C.E.}

Ancient China's connection with Central Asia (the 'Western Regions 西域) started in the Han Dynasty (noted as 'the Han') and its earliest credible record (probably the only direct record) is found in the 'Ranked Biographies of the Dayuan' in the Records of the Grand Historian (also known in Chinese as the Shiji ${ }^{1}$; the term used to refer to this historical document from here

${ }^{1}$ This paper uses Li Hanwen's annotation to Shiji as the texts of analysis. (see Li, 2016) 
on) written by the official historiographer Sima Qian (also translated as SsuMa Ch'ien).

The northern nomads had long been a threat to Chinese kingdoms (Tong, 1946, 2006; Beckwith, 2009; Liu 2010). In the early period of the Han Dynasty, the Xiongnu were in a dominant position in East-Central Asia, and the Han emperors had to resort to 'He'qin' with the Xiongnu (marrying off Han emperor's sisters or daughters to chiefs of the Xiongnu) in order to make peace on their borders. However when the Emperor Wu of Han was in power, this strategy could no longer effectively prevent Xiongnu's incursions into Han territory. The Han would often defeat the Xiongnu in battle, but these victories provided only temporary respite and could not prevent continued Xiongnu's incursions (Zhang and Liu, 2015).

Against this background, as Sima Qian commented, the Han needed allies in Central Asia as a counterbalance to the Xiongnu's regional power and influence ( $\mathrm{Li}, 2016)$. Such alliances would have obvious benefits to the Han in securing their borders. It is worth noting here that, although many researchers reveal the importance of connections between ancient China and Central Asia from economic and cultural perspectives, the original motivation for building these connections were strategic and security concerns. The Han needed allies to balance the threats from the Xiongnu, and this strategic objective remained the top priority of the Han's relationship with Central Asian nations.

\begin{tabular}{|c|c|c|c|c|c|}
\hline & $\begin{array}{l}\text { Target } \\
\text { country }\end{array}$ & $\begin{array}{l}\text { Mutual } \\
\text { interest }\end{array}$ & $\begin{array}{l}\text { Costly } \\
\text { signal }\end{array}$ & $\begin{array}{l}\text { Good } \\
\text { understanding } \\
\text { of the Han's } \\
\text { interests }\end{array}$ & Consequence \\
\hline 1 & Yuezhi & Yes & No & No & Failed \\
\hline 2 & $\begin{array}{l}\text { Wu Sun } \\
\text { and } \\
\text { others }\end{array}$ & Yes & Yes & No & Failed \\
\hline 3 & $\begin{array}{l}\text { Wu Sun } \\
\text { and } \\
\text { others }\end{array}$ & Yes & Yes & Yes & Succeeded \\
\hline
\end{tabular}

Table 1: The three rounds of interaction between the Han and Central Asian nations

Table 1 compares the interaction between the Han and Central Asian nations for the establishment of a strategic alliance. Three rounds of interaction can be identified. In the first round, Zhang Qian and his delegation left the Han territory and travelled west to find the Yuezhi. The Yuezhi had been invaded by the Xiongnu, and the King of Yuezhi was brutally murdered. The King's 
son led an exodus of the Yuezhi from their homelands, hoping for an opportunity for retaliation. The Han thus regarded the Yuezhi as a potential ally against Xiongnu ( $\mathrm{Li}, 2016)$. However, having been captured and held by the Xiongnu, Zhang Qian was delayed in his arrival in Yuezhi territory. By the time he eventually arrived in Yuezhi territory, the Yuezhi had conquered the Da Xia, a Greek colony originally situated on the north bank of the Amu Darya River (Liu, 2010). The Yuezhi declined Zhang Qian's alliance proposal on the pretext of having no interest in retaliation as their new territory was fertile and secure, far from the Xiongnu, and even further from the Han ( $\mathrm{Li}$, 2016). However, while it might have been true that the Yuezhi were not interested in retaliation, they still had a shared interest with the Han in defending against the Xiongnu. This view is supported by the fact that they eventually sent envoys and built a relationship with the Han later in the third round of negotiation.

In this first round, although the Han and the Yuezhi shared common interests in defending against the Xiongnu, the Yuezhi knew little of either the Han's determination to fight against the Xiongnu or the Han's military capability. Zhang Qian's mission to the Yuezhi might have been unsuccessful due to the lack of a costly signal. Although Zhang Qian could prove his identity as an envoy of the Han, he was neither in a formal delegation nor offering considerable gifts after been captured by the Xiongnu troops ( $\mathrm{Li}$, 2016). Therefore, the Yuezhi could not possibly formulate a good understanding of the Han's interest in cooperation. It was, therefore, no surprise that the King of Yuezhi, suspecting deception, decided not to make an alliance with the Han.

In the second round of signalling, the Han switched their attention from the Yuezhi to the Wu Sun. The Wu Sun were an independent state prior to being invaded by the Xiongnu's troops. Kunmo, the King of Wu Sun, struggled to re-build Wu Sun's independence; however, any independence he achieved was relative and fragile. Zhang Qian believed that the Han and the Wu Sun shared common interests in strategic terms, because the Han wanted additional support in deterring the Xiongnu, while the Wu Sun desired absolute independence from the Xiongnu's control. He further suggested in his proposal to Emperor Wu of the Han that once the Han made an alliance with the Wu Sun, the Han could thereby build foreign relations with the Da Xia and other Central Asian nations ( $\mathrm{Li}, 2016$ ).

Zhang Qian subsequently went to Central Asia for a second time. This time the Han sent costly signals to the Central Asian nations through a large delegation offering substantial valuable gifts. The Shiji records that the delegation had an entourage of 300, bringing 600 horses, tens of thousands of cows and sheep, and hundreds of thousands gifts made from precious 
metals and cloths (Li, 2016). When Zhang Qian arrived in Wu Sun's territory, he despatched his associate envoys to other Central Asian nations. These included the Dawan (in what is modern Ferghana in Uzbekistan, see Liu, 2010), the Kangju (sometimes translated as Kangkeu, and located in what is now Tashkent and the Chu, Talas, and middle Jaxartes basins), the Yuezhi, the Da Xia (Darya), and the Anxi (Persia under the rule of the Parthians).

Regardless of the costly signals that the Han sent with the large delegation and precious gifts, Kunmo, the chief of the Wu Sun still declined the Han's proposal. He was not sure whether the Han were powerful enough to protect the Wu Sun from the Xiongnu. The Shiji records that as the Wu Sun were geographically distant from the Han, they had no knowledge of the Han's capability; the Wu Sun were close to the Xiongnu and had been a dependent state of the latter for a considerable period; therefore, the Wu Sun nobles all feared the Xiongnu ( $\mathrm{Li}, 2016)$.

In other words, even with common interests and costly signals, the Wu Sun had not built knowledge about the Han that fitted the Han's cooperative signals, and thus could not generate a good understanding of the Han's strategic interests. As a result, the second round of signalling failed.

In the third round, the Han repeated the signalling process and improved the Wu Sun's understanding of the Han's economic and military capabilities by inviting a delegation of the Wu Sun to visit the Han. The 'Ranked Biographies of the Dayuan' record that the Wu Sun envoys noted that the Han was rich and mighty with a huge population. They reported what they had seen to their King. The Wu Sun thereby started to take the Han's proposal on strategic cooperation increasingly seriously. The following year, other Central Asian nations that Zhang Qian and his delegation had visited all sent envoys to the Han. The Han's foreign relations with these states were consequently established in more formal ways ( $\mathrm{Li}, 2016)$. Although not by strict definition bilateral military alliances, these foreign relations were of a similar nature. As the 'Ranked Biographies of the Dayuan' recorded, the Xiongnu took these actions as betrayal and planned an assault against the Wu Sun( $\mathrm{Li}, 2016)$. In other words, the Wu Sun's decision to establish formal relations with the Han suggested that they were willing to accept the Han proposal to change the regional order in Central Asia.

The success story of the third round of signalling cannot be separated from the first two rounds. Trust-building is a process of signalling and knowledgebuilding. If the Han had not sent Zhang Qian to the Yuezhi and the Wu Sun, Central Asian nations could not possibly have known about the Han and the Han's cooperative determination, and they would not send envoys to Han. However, it was only when the Wu Sun and other Central Asian nations 
learnt of the Han's economic and military capabilities that they were able to form a good understanding of Han strategic interests and, therefore, enter a collaboration based on trust.

\section{Case Two: BRI empowering China as a Global Power}

President Xi Jinping first proposed establishing an economic belt across the trans-Eurasian region at Nazarbayev University in Astana, Kazakhstan on 7 September 2013. Nicknamed 'the new silk road', the project would affect 3 billion people in this region, in areas of conventional energy and mineral resources, and encompass collaboration in technology, investment, finance and services (Xinhua News, 2013). This message was quickly followed by a second speech in Indonesia on 3 October 2013 on the launch of the MSRI project. This project proposed to focus on China's ASEAN neighbours for common development and prosperity (Xi, 2013:322).

There have been two main trust-building signals delivered in relation to BRI projects, and they were clearly elaborated in President Xi's three-and-halfhour foreign strategies speech on 18 October 2017 at the $19^{\text {th }}$ National Congress of the People's Republic of China. One is the 'economic and politically pro-activeness' signal, the other is the 'military conservativeness' signal. This paper illustrates that the former signal is better accepted than the latter because it fits international audiences' understanding of China's interests better.

The signal 'economic and political pro-activeness' is largely reflected by the concepts of 'striving for achievement' and a 'community of a shared future for mankind'. This rhetoric suggests that China sees itself playing an increasingly influential role in global economic and political affairs. The BRI project is a continuation of China's 'opening up' policy as it supports the expansion of Chinese enterprises abroad as a means to facilitate industrial upgrading at home. It is also intended as a means of increasing Chinese outward foreign direct investment (FDI) and trade, and in advancing the internationalisation of the Chinese currency (Babatunde, 2015:130-131). The importance of the BRI to Chinese government global strategy is undisputed as it was officially enshrined in the 19th National Party Congress (NPC) held in October 2017. The same congress where Xi delivered the above mentioned speech (Vangeli, 2018:59). The purpose of the BRI is therefore not only to impact the global political economy but also to change the way others relate to and think about the global political economy, their role in it, and their dialogue with China (Vangeli, 2018:59-60). This strategy is built upon a desire for a shift in authority in the global order, and in facilitating the emergence of a multipolar structure, rather than a hegemonic structure (Breslin 2013). 
Another signal that the BRI delivers is military conservativeness, which is mostly reflected by the concepts of a 'community of a shared future' and a 'new model of international relations'. The ancient Silk Road is a symbol of peace among the nations along the road, and China hopes to integrate this symbol into BRI projects. The notion of 'peaceful development' is a cornerstone of China's foreign policies. However, in contrast to Hu Jintao's 'peaceful development', Xi's signal of military conservativeness is characterised by a subtle shift from absolute pacifism and the principle of non-interference. Xi's speech at the Central Bureau in 2013 indicates that China advocates dealing with international security issues through dialogue and negotiation, and to solve disputes with mutual trust, mutual understanding and mutual concession. However, this is qualified by a precondition that China's core interests should not be violated (Qian and Liu, 2013). Xi's speech at Geneva further suggests that China might intervene in international security crises if necessary. Xi states that 'a country cannot have security while others around it are in turmoil, as threats facing other countries might affect it, too. When neighbours are in trouble, instead of strengthening one's own fences, one should extend a helping hand to them... All countries should pursue common, comprehensive, cooperative and sustainable security' (Xi, 2017a). This shift in relation to international intervention appears to be a response to previous criticisms from the West of Chinese inaction in international peacekeeping and crises settlement.

How have international audiences responded to these two signals? This research examines commentaries on President Xi's speech of 18 October 2017 from all major English news publications in the Lexi-Nexis database, with publishing dates ranging from 18 October 2017 to 17 October 2018. There were in total 45 publications from 14 countries presenting relevant comments. This research mainly searches for commentary in English language sources, with some commentary in non-English speaking media in Japan, Thailand, and South Korea included in the analysis. The sampled publications may not, therefore, fully reflect general public opinion about BRI in these countries, or globally, but they help illustrate perceptions and responses to the two signals by global audiences in the given time period.

Figure 2 illustrates the acceptance rate of the two signals among the samples. 'Accept' means the signal is accepted as it reflects the true intention of China. The result shows that nearly $60 \%$ of the sample agree that China's signal of economic and political pro-activeness reflects China's true intention, while less than $5 \%$ do 'not accept' the signal as China's true intention. About $38 \%$ of the sample do not show a clear position. In contrast, the signal of military conservativeness is less accepted as reflecting China's 
true intention. Less than $5 \%$ of the sample accept this signal while more than $20 \%$ express a clear stance that they do not believe China will act in accordance with the signal of military conservativeness.

\section{Acceptance rate of the signals}

military conservativeness

economic and political proactiveness

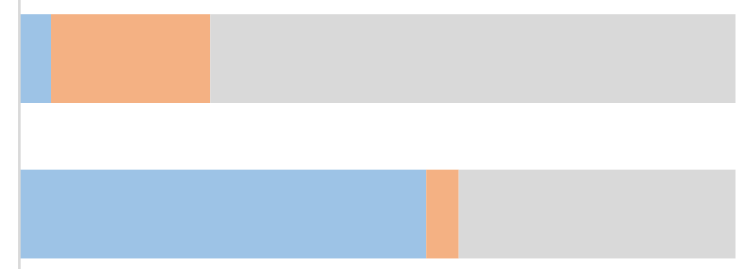

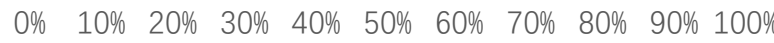

-accept $\quad$ not accept $\quad$ neutral

\section{Figure 2. Audience acceptance of the two signals}

Figure 3 shows how the audiences responded differently in their attitudes to the intended goals related to the two signals transmitted by Xi's speech on 18 October 2017. Some international audiences might accept a signal as truly reflecting China's intentions, but they might not welcome this changing role of China. Of the samples collected, 14 out of 45 welcomed China playing an increasing role in international politics, and some of the views were 'very positive'. However, 10 samples express 'negative' or 'very negative' attitudes. In contrast, international audiences expressed more negative attitudes towards the signal of 'military conservativeness' than that of 'economic and political pro-activeness'. Only three out of 45 samples express positive attitudes to China's signal of 'military conservativeness', while 21 samples express 'negative' or 'very negative' attitudes.

Audiences' attitudes towards Xi's signals

Military conservativeness

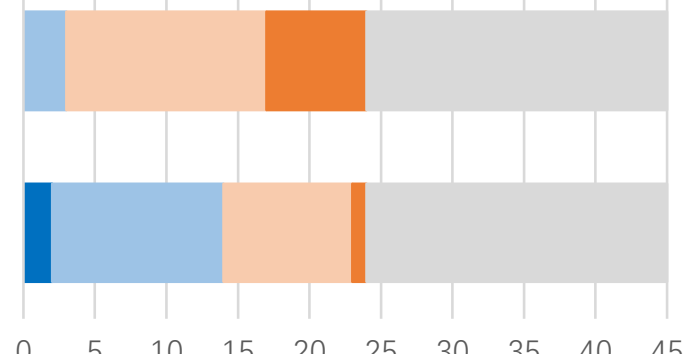

Economic and political proactiveness

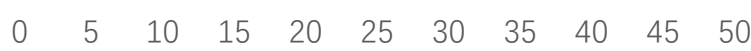

-very positive positive negative very negative neutral

Figure 3. Audience attitude towards Xi's signals

Table 2 compares the level of acceptance of the two strategic signals that China sent via Xi's speeches related to the BRI. In terms of mutual interests, 
both China's 'economic pro-activeness' and 'military conservativeness' fit other countries' interests. The Asian Development Bank estimates the cost of infrastructure needs for development in the Asia-Pacific to reach around USD 26 trillion by 2030 (OECD, 2019). China's huge investment in the BRI countries' infrastructure and other projects can substantially contribute to the development of these countries. China also intends to be more involved in global and regional governance, which it sees as also benefiting BRI countries. China has also stated its intention to remain militarily conservative and has made promises of no military expansion. Xi's speech in 2017 also states that China will provide protection when neighbours are threatened (Xi 2017b). This signal also fits neighbouring countries' security interests.

\begin{tabular}{|l|cc|}
\hline \multicolumn{1}{|l|}{} & $\begin{array}{c}\text { 'Economic and } \\
\text { political pro- } \\
\text { activeness' }\end{array}$ & $\begin{array}{c}\text { 'Military } \\
\text { conservativeness' }\end{array}$ \\
\hline Mutual interests & $\sqrt{ }$ & $\sqrt{ }$ \\
Costly signals & $\sqrt{ }$ & \\
Good understanding of & Relatively good & Relatively poor \\
interests & & \\
Acceptance (of samples) & Acceptance Rate & Acceptance Rate \\
Accept & $56.8 \%$ & $4.4 \%$ \\
Neutral rate & $38.6 \%$ & $73.3 \%$ \\
Non-Accept & $4.5 \%$ & $22.2 \%$ \\
\hline
\end{tabular}

Table 2. Comparing the trust-building of the two signals

Both 'economic and political proactiveness' and 'military conservativeness' are costly signals. For the signal of 'economic and political proactiveness', Xi's speech at the 19th Congress of Chinese Communist Party states that 'it will be an era that sees China moving closer to the centre stage and making greater contributions to mankind' (Xi, 2017b). China has made enormous direct investments in BRI partner countries, containing the projects that relate to global governance in climate change, poverty, and marine governance (Xinhua News, 2019). These investments are the direct sunk cost of China's signal on economic and political pro-activeness. 
For the signal of military conservativeness, President Xi and other Chinese leaders have repeatedly stated China's determination in military conservativeness in many speeches internationally and domestically. For instance, $\mathrm{Xi}$ made a speech on the $70^{\text {th }}$ anniversary of victory in the AntiFascist War, promising that China will never seek a hegemonic position or expansion of her power and that China will never impose on other peoples its tragic experiences during that conflict ( $\mathrm{Xi}, 2015)$. White Papers from Press Office of Ministry of National Defence also emphasize China's essentially defensive strategy (Press Office of Ministry of National Defence of the PRC, 2010, 2015, 2019). These broadcasts can be seen as attaching high audience cost to the signal of 'military conservativeness'.

The sunk costs of 'military conservativeness' are also visibly high. To reinforce the peaceful role of the BRI and its relevant actors, and to move away from geopolitical and security concerns, China has stressed the deployment of military forces overseas only to deal with non-traditional security challenges along the BRI route, such as maritime search and rescue missions, piracy, drug trafficking and environmental risks (Chen et al, 2017). Deploying such defensive measures attaches a high sunk cost to the signal of 'military conservativeness'.

Despite the high 'hand-tying' and sunk costs, both signals are, in general, not well accepted by international audiences. Examining the samples of this research, there is still considerable scepticism of China's true intentions. China's opaque definition of its interest boundaries in BRI projects is the major reason. This problem has led to numbers of the comments examined taking a particularly negative view of the BRI. These see a hidden agenda, accusing China of interference in the domestic affairs of other countries through the creation of 'debt traps.'

However, international audiences still respond differently to these two signals (see Figures $2 \& 3$ ). International audiences tend to interpret the 'economic and political pro-activeness' signal as an indication of China's quest for increasing economic and political influence internationally. The decline of US international leadership marked by the US withdrawal from several important international treaties and organisations has left a vacuum in international leadership. This worries many nations because they believe in the positive role of great powers in global governance. Therefore, China's willingness to take on more responsibilities in international affairs, regardless of whether it can fill the vacuum left by the US or not, is seen as a positive development. More importantly, international audiences believe that growing international economic and political influence would largely benefit China's grand strategic goal of the 'rejuvenation of the Chinese 
nation'. This signal fits international audiences' understanding of China's strategic interests.

In contrast, the signal 'military conservatism' is more confusing to international audiences. China's peaceful rise has been of mutual interest to China and the rest of world, at least until around 15 years ago. Yet how does the rise of a more powerful China in the future fit with other countries expectations, especially where ideological competition seems to be inevitable given China's different path of development? The scepticism expressed in the comments examined mainly arise from China's increasing military expenditure (Liu et al., 2019). Commentators are acutely aware of China's increasingly muscular stance in the South China Sea, such as the construction of a man-made island and other new military facilities, and the denial of international arbitration. There is also concern over the development of overseas military harbours elsewhere.

The People's Liberation Army Navy (PLAN) has been focusing on developing 'blue water' capabilities to guarantee the security of the BRI (Fanell, 2019). The PLAN has also established a broader 'security supply chain' with Indian Ocean partners, for example, Pakistan and Bangladesh, and Middle Eastern and African countries ( $\mathrm{Ma}, 2019$ ). This not only improves its operational proficiency but also normalises its presence in this region (Wuthnow, 2017). However, while this rapid development of the PLAN along the BRI route is clear to many international observers, the increasing role and presence of the PLAN is often intentionally left out of Chinese official narratives. This lack of transparency increases the scepticism surrounding China's motives.

\section{Conclusion}

This paper started with the puzzle of international audiences' mistrust of China's cooperative signal sending via the BRI, and it attempts to investigate how trust can be built across different narratives. It illustrates that trust-building is a continuing process of signalling and knowledge building. With the existence of common interests, only when the signals fit a counterparty's knowledge about the signal sender, can they develop a good understanding of the sender's cooperative interests and, therefore, trust the sender. In this process, the signal sender's 'brightness' - that is, being honest regarding their self-interest and cooperative intentions - is the necessary condition whereby the signals can fit others' knowledge.

However, it is worth noting that this explanatory framework is valid only for a one-way signalling process where the signal sender and receiver are in an 
asymmetric power relationship. In other words, the signal sender has minimal risk of exploitation by the receiver in their strategic cooperation.

The two case studies help to demonstrate the dynamic nature of trustbuilding in this one-way signalling process. In the first case study, when Zhang Qian and his delegation visited the Wu Sun and other Central Asian nations, they sent costly signals by bringing a huge amount of gifts that were intended to show the Han's determination and sincerity in strategic cooperation against the Xiongnu. However, the Wu Sun and others decided not to trust the Han. The Wu Sun knew the Han's interests in balancing the threat from the Xiongnu, but they were cautious about cooperating because they had little understanding of the capability of Han. The Wu Sun's interests might be seriously harmed if the Han were weak and were seeking to deceive the Wu Sun to gain an ally to bear the brunt of an offensive against the Xiongnu. However, the Wu Sun's knowledge of the Han concurred with the Han's cooperative signal in the third round of signalling after the Wu Sun had sent envoys to the Han. This eventually led to an alliance between the Han and the Wu Sun.

In the second case study of contemporary events, China has sent costly signals of cooperation by making huge infrastructure investments in BRI partner countries. However, these have not received the expected trust in return. The international audiences of the BRI are aware of China's capabilities, but uncertain about its intentions. How and what benefits can China gain from its huge investments in BRI countries? This is the question that concerns international audiences.

Therefore, China needs to further clarify its interests and intentions and to keep sending cooperative signals that help counterparties develop their knowledge of China and its cooperative interests if trust-building, and by extension the BRI, is to be successful. Moreover, China needs to be cautious about the 'cost' of its signals. If the cost of a signal appears higher than the perceived gain for China, international audiences will likely form a different interpretation of China's cooperative interests, leading to a lack of trust.

This paper has argued that trust in strategic cooperation is the result of a series of signalling and knowledge building initiatives in which the signal sender's 'brightness' acts as a defining factor. While this trust-building process can decrease the risk for cooperating states in trusting the signal sender, it cannot guarantee this trust will never be betrayed. However, any betrayal would undermine the credibility of a signal sending state, which would have likely involve negative consequences for that state. For instance, Emperor Wu of the Han attempted to reshape the regional order in Central Asia by making alliances with the Wu Sun and other Central Asian nations. 
However, this alliance was not honoured by later Han leaders, possibly because the Xiongnu confederacy disintegrated and they were no longer a threat to the Han. However, the Han's failure to honour earlier commitments to its allies had serious consequences. The Central Asian nations turned against the Han, who had to wage numerous wars at enormous military and economic expense to secure their western border. This resulted in the decline of the Great Han Empire in the final years of Emperor Wu's reign. 


\section{References}

Babatunde, M. A. (2015) 'Promoting Connectivity of Infrastructure in the Context of One Belt, One Road Initiatives: Implications for Africa in the Fourth Industrial Revolution', Fostering Trade in Africa: Trade Relations, Business Opportunities and Policy Instruments, Eds. Odulary G., Hassan M., and Babatunde M. Chan: Springer Nature Switzerland. pp. 11-152.

Baltensperger, M. and Dadush, U. (2019) The Belt and Road turns five. Policy Contribution (1). Available at: https://bruegel.org/wpcontent/uploads/2019/01/PC-01 2019 .pdf (accessed 16 August 2019).

Beckwith, C. I. (2009) Empires of the Silk Road: A History of Central Eurasia from the Bronze Age to the Present. Princeton: Princeton University Press.

Blanchard, J-M. F. (2018) 'China's Maritime Silk Road Initiative (MSRI) and Southeast Asia: A Chinese 'pond' not 'lake' in the Works', Journal of Contemporary China, 27(111):329-343.

Booth, K. and Wheeler, N.J. (2008) The security dilemma: Fear, cooperation and trust in world politics. Houndmills: Palgrave Macmillan.

Breslin, S. (2018) 'The Belt and Road as "Strategic Signalling"', Understanding the Belt and Road Initiative: Dynamics, Prospects and Implications (Conference), Beijing, China, 22-23 October 2018.

Breslin, S. (2013). 'China and the global order: Signalling threat or friendship?', International Affairs, 89(3), 615-634. Retrieved April 28, 2020, from www.jstor.org/stable/23473846

Callahan, W.A. (2016). 'China's "Asia Dream": The Belt Road Initiative and the new regional order', Asian Journal of Comparative Politics, 1(3):226-243.

Chen, L., Song, G. and Wei, Z. (2018) 'Xin Shidai Renming Haijun 'Zouchuqu' Wenti' [On 'go global' strategy in new era]. Haijun Gongcheng Daxue Xuebao, [Journal of Naval University of Engineering] 15(1): 28-33.

Datta-Ray, D.K. (2015) The Making of Indian Diplomacy. New York: Oxford University Press.

De Vreese, C. and Boomgaarden, H.G. (2005) 'Projecting Eu Referendums: Fear of Immigration and Support for European 
Intergration', European Union Politics, 6(1): 59-82.

De Vreese, C. and Boomgaarden, H.G. (2006) 'Media Effects on Public Opinion About the Enlargement of the European Union', Journal of Common Market Studies, 44(2):419-36.

Fanell, J. E. 'Asia Rising China's Global Naval Strategy and Expanding Force Structure', Naval War College Review, 72(1). Available at https://digital-

commons. usnwc.edu/cgi/viewcontent.cgi?article $=7871 \&$ context $=$ nwcreview. Retrieved on April 28, 2020

Fearon, J. (1997) 'Signaling Foreign Policy Interest: Tying Hands versus Sinking Costs', The Journal of Conflict Resolution, 41(1):68-90.

Franzosi, R. (1998) 'Narrative Analysis-Or Why (And How) Sociologists Should be Interested in Narrative', Annual Review of Sociology, 24:517-554. Available at: www.jstor.org/stable/223492 (accessed 22 January 2020).

Glaser, C.L. (2010) Rational Theory of International Politics: The Logic of Competition and Cooperation. Princeton University Press.

Guo, D. (2016) Interpreting Zuo Zhuan: Chinese Classic Book. Hong Kong: Zhonghua Shuju.

Hall, T. and Yarhi-Milo K. (2012) 'The Personal Touch: Leaders' Impressions, Costly Signalling, and Assessments of Sincerity in International Affairs', International Studies Quarterly, 56(3):560-573

Hoffman, A.M. (2002) 'A Conceptualization of Trust in International Relations', European Journal of International Relations, 8(3):375-401.

Hollis, M. (1998) Trust with Reason. Cambridge: Cambridge University Press.

Hu, P. S., and Zhang, M.Y. (2017) Li Ji (Annotation). Beijing: Zhonghua Shuju.

Irshad, M.S., Qi, X., Li, X. and Arshad, H. (2016) 'Deltoid Analysis of Pakistan-ASEAN-China Free Trade Agreements and Opportunities for Pakistan', Asian Economic and Financial Review, 6(5): 228-237. Available at SSRN: https://ssrn.com/abstract=2769335 (accessed 21 April 2020).

Jervis, R. (1976) Perception and Misperception in International Politics. Princeton: Princeton University Press.

Juan, J. (2018) 'As China takes "center stage" Europe stands at a 
crossroads', Deutsche Welle, 15 February 2018. Available at https://www.dw.com/en/as-china-takes-center-stage-europe-standsat-a-crossroads/a-42590805 (accessed 12 July 2020)

Kydd, A.H. (2000) 'Trust, Reassurance, and Cooperation', International Organization, 54(2):325-357.

Kydd, A.H. (2001) 'Trust-building, Trust Breaking: The Dilemma of NATO Enlargement', International Organization, 55(4):801-828. Available at: www.jstor.org/stable/3078616 (accessed 23 January 2020).

Kydd, A.H. (2005) Trust and Mistrust in International Relations. Princeton: Princeton University Press.

Kynge, J. (2018) 'Chinese contractors grab lion's share of silk road projects', Financial Times. 24 January. Available at: https://www.ft.com/content/76b1be0c-0113-11e8-96509c0ad2d7c5b5 (accessed 21 April 2020).

Larson, D.W. (1997) Anatomy of Mistrust: US-Soviet Relations. New York: Cornell University Press.

Li, D. (2015) 'Jiedu Zhongguo Junfei Kaizhi' [China's military expenditure], Zhongguo Jingmao Daoka, [Journal of Chinese Eonomics and Trade], 6:75-77.

Li H.W. (2016) Shiji Jingzhu Quanyi [Full annotation to the Records of the Grand Historian], Beijing: Beijing Lianhe Chuban Gongsi

Liang T. (2015) Mengzi Jiedu [Annotation to Mengzi], Beijing: Zhongguo Renmin Daxue Chubanshe.

Liu, H. and Lim, G. (2019) 'The Political Economy of a Rising China in Southeast Asia: Malaysia's Response to the Belt and Road Initiative', Journal of Contemporary China, 28(116):216-231.

Liu, H., Xiao, C. and Zhang, C. (2019) 'Spatial Big Data Analysis of Political risks along the Belt and Road', Sustainability, 11(2216). Available at doi:10.3390/su11082216 (accessed 16 August 2019).

Liu, X.R. (2010) The Silk Road in World History. Oxford: Oxford University Press.

Ma, D. (2019) 'Zhongguo junfei zhichu zheshe d zhengce quxiang' [the policy orientation reflected by China's military expenses], Ministry of National Defense of the People's Republic of China, 20 March 2019. Available at: http://www.mod.gov.cn/jmsd/201903/20/content 4837902.htm (accessed 21 April 2020).

Organisation for Economic Co-operation and Development (OECD) (2019) 
'Infrastructure Connectivity', Japan G20 Development Working Group, January 2019. Available at:

https://www.oecd.org/g20/summits/osaka/G20-DWG-BackgroundPaper-Infrastructure-Connectivity.pdf (accessed 11 April 2020).

Patterson, M. and Monroe, K.R. (1998) .Narrative in Political Science', Annual Review of Political Science, 1(1):315-31.

Press Office of Ministry of National Defense of the PRC (2011) '2010 Nian De Zhongguo Guofang' [China's National Defense 2010], Ministry of National Defense of the PRC, 31 March 2011. Available at: http://www.mod.gov.cn/regulatory/2011-03/31/content 4617810.htm (accessed 21 April 2020).

Press Office of Ministry of National Defense of the PRC (2015) 'Zhongguo

De Junshi Zhanlue' [China's Military Strategy], Ministry of National Defense of the PRC, 26 May 2015. Available at:

http://www.mod.gov.cn/regulatory/2015-05/26/content 4617812.htm (accessed 21 April 2020).

Press Office of Ministry of National Defense of the PRC (2019) 'Xin Shidai De Zhongguo Guofang' [China's national defense in the new ear], Ministry of National Defense of the PRC, 24 July 2019. Available at: http://www.mod.gov.cn/regulatory/2019-07/24/content 4846424.htm (accessed 21 April 2020).

Pu, X.Y. (2017) 'Ambivalent accommodation: status signalling of a rising India and China's response', International Affairs, (93)1:147-163.

Pu, X.Y. (2019) Rebranding China: Contested Status Signaling in the Changing Global Order. Stanford: Stanford University Press.

Qian, T. and Liu, H. (2013) 'Xinhua Shipping: Yao Heping Fazhan Ye Jue Bu Xisheng Hexin Liyi' [Xinhua commentary: advocating for peaceful development without scarifying core interests], People.cn, 1 February. Available at: http://opinion.people.com.cn/n/2013/0201/c100320399428.html (accessed 12 April 2020)

Rathbun, B.C. (2011) 'Before Hegemony: Generalized Trust and the Creation and Design of International Security Organizations', International Organization, 65(2): 243-73.

Rathbun BC (2012) Trust in International Cooperation: International Security Institutions, Domestic Politics and American Multilateralism. Cambridge: Cambridge University Press.

Rousseau, D.M., Sitkin, S.B. and Burt, R.S. (1998) 'Not So Different after All: A Cross-Discipline View of Trust', Academy of Management Review, 23(3):393-404. 
Russel, D. and Berger, B. (2019) 'Navigating the Belt and Road Initiative', the Asia Society Policy Institute. June 2019. Available at https://asiasociety.org/sites/default/files/201906/Navigating\%20the\%20Belt\%20and\%20Road\%20Initiative 2.pdf (accessed 11 April 2020)

Sidaway, J.D. and Woon, C.Y. (2017) 'Chinese Narratives on "One Belt, One Road" in Geopolitical and Imperial Contexts', The Professional Geographer, 69(4):591-603.

Somers, M.R. (1994). 'The narrative constitution of identity: A relational and network approach', Theory and Society, 23(5):605-649.

Tong, S.Y. $(1946,2006)$ Chun Qiu Shi [The history of the Spring and Autumn Period], re-edited by Tong Jiaoying. Hong Kong: Zhong Hua Shu Ju.

Vangeli, A. (2018). The Normative Foundations of the Belt and Road Initiative. New York: Springer

Wheeler, N.J. (2012) Trust-building in international relations. Peace Prints: South Asian Journal of Peacebuilding, 4(2):1-14. Available at https://pdfs.semanticscholar.org/8c0d/8cff72824466e303902f1f6ca17 d7d5d3a9d.pdf (accessed 11 April 2020).

Wood, F. (2002) The Silk Road: Two Thousand Years in the Heart of Asia. Los Angeles: University of California Press.

Wuthnow, J. (2017) 'Chinese Perspectives on the Belt and Road Initiatives: Strategic Rationales, Risks, and Implications', Institute For National Strategic Studies: China Strategic Perspectives, no.12. Washington: National Defense University Press. Available at https://inss.ndu.edu/Portals/68/Documents/stratperspective/china/Chi naPerspectives-12.pdf Retrieved on April 28, 2020

Xi, J. (2014). Xi Jinping Tan Zhiguo Lizheng [Xi Jinping: The Governance of China]. Beijing: Waiwen Chubanshe [Foreign Language Press].

Xi J. (2015) 'Speech on the 70th anniversary of the victory in the AntiFascist War', Beijing, 3 September 2015. Available at: http://news.cnr.cn/special/ybzb/list/20150903/t20150903 519757913 shtml (accessed 14 April 2020).

Xi, J. (2017a) 'Work together to build a community of shared future of mankind', speech at the United Nations Office at Geneva, 18 January 2017.

Available at: http://www.xinhuanet.com/world/201701/19/c 1120340081.htm (accessed 14 April 2020). 
Xi, J. (2017b) 'Speech on the 19th Party's Congress of Chinese

Communist Party', Great Hall of the People, Beijing, 18 October 2017.

Available at:

http://cpc.people.com.cn/n1/2017/1028/c64094-29613660.html

(accessed 14 April 2020).

Xinhua News (2013) 'Xi Jinping Fabiao Zhongyao Yanjiang Huyu Gongjian 'Sichou Zhi Lu Jingji Dai' [Xi Jinping gave important speech calling on building up Silk Road Economic Belt], Xinhua Net, 07 September 2013. Available at: http://www.xinhuanet.com/politics/2013-

09/07/c 117272280.htm (accessed 11 April 2020).

Xinhua News (2019) 'Zhongguo tuidong wanshan quanqiu zhili duo you xin zuowei' [China's multiple efforts in driving and perfecting global governance], Xinhua Net, 26 June, 2019. Available at:

http://www.xinhuanet.com/2019-06/26/c 1124670734.htm (accessed 11 April 2020).

Yahuda, M. (2013) 'China's New Assertiveness in the South China Sea', Journal of Contemporary China, 22(81):446-459.

Yean, T.S. (2018) 'Chinese Investment in Malaysia: Five Years into the BRI', ISEAS Yusof Ishak Institute. Available at:

http://hdl.handle.net/11540/8046 (accessed 19 August 2019).

Zaller, J. (1992) The Nature and Origin of Mass Opinion. New York: Cambridge University Press.

Zhang J. (2006) Hanfeizi Yizhu [Annotations to Hanfeizi]. Shanghai: Shanghai Guji Chubanshe.

Zhang J. (2012) Xunzi Yizhu [Annotations to Xunzi]. Shanghai: Shanghai Guji Chubanshe.

Zhang Y.I. and Liu C. (2015) Han Shu [Annotations to Han Shu]. Beijing: Zhonghua Shuju.

Zucker, L.G. (1977) The Role of Institutionalization in Cultural Persistence. American Sociological Review 42(5):726-43. 